\title{
Molecular Detection, not Extended Culture Incubation, Contributes to Diagnosis of Fungal Infection
}

\author{
Alex Zhu ( $\nabla$ alexzhu2022@u.northwestern.edu ) \\ Northwestern University Judd A and Marjorie Weinberg College of Arts and Sciences \\ https://orcid.org/0000-0002-0506-8405 \\ Chao Qi \\ Northwestern University Feinberg School of Medicine
}

\section{Research article}

Keywords: Fungal culture, ITS PCR

Posted Date: August 26th, 2020

DOI: https://doi.org/10.21203/rs.3.rs-55585/v1

License: (a) (i) This work is licensed under a Creative Commons Attribution 4.0 International License. Read Full License 


\section{Abstract}

Background. Despite of low sensitivity, fungal culture remains one of the key methods for diagnosing and treatment of fungal infections as it identifies etiology at genus and species level and offers susceptibility testing. The Manual of Clinical Microbiology recommends that fungal cultures screening for all pathogens should routinely be held for 4 weeks to maximize the recovery of slow growing species. Information on the optimal fungal culture time in the era of expansion of immunocompromised populations is lacking. The goal is to review our experience with fungal culture in order to determine the optimal culture incubation time; to review our experience of broad-range ITS PCR for diagnosis of culture negative fungal infections.

Methods. Fungal culture and ITS PCR results from January 1, 2013 to December 31, 2017 were reviewed.

Results. Ninety six percent of positive cultures (4058) were detected in the first seven days of incubation. During the second week of incubation, $2.8 \%$ of positives (111) were detected from day 8 to 10 , and $1.7 \%$ (71) were detected from day 11 to 14 . Only $0.1 \%$ of positive culture were detected in the third week of incubation, and no positive culture was detected in the fourth week of incubation. No Clinical significance of fungal isolates recovered after 14 days. Clinical significant pathogens were detected in $0.2 \%$ culture negative samples.

Conclusion. Extending culture incubation beyond two weeks did not generate clinical relevant results. When culture failed to make laboratory diagnosis, ITS PCR produced clinical significant results.

\section{Introduction}

While the number of immunocompromised patients increases as a result of the widespread adoption of aggressive immunosuppressive therapy and the use of new immune modifying drugs, invasive fungal infections becomes an emerging problem (1) because of the high mortality rate associated with these infections (2). The 12-week mortality rate of patients with invasive fungal infections was reported as high as $46.7 \%$ for adult hematopoietic stem cell transplant recipients and $29.6 \%$ for solid organ transplantation patients (3). Prompt initiation of antifungal therapy is the most important intervention to decrease mortality in patients with invasive fungal infection (4).

Despite of low sensitivity, fungal culture remains one of the key methods for diagnosing and treatment of fungal infections as it identifies etiology at genus and species level and offers susceptibility testing. Recovery of fungal pathogens relies on a numbers of factors, including specimen quality, appropriate specimen collection and transport, and optimal incubation condition and time. The Manual of Clinical Microbiology recommends that fungal cultures screening for all pathogens should routinely be held for 4 weeks to maximize the recovery of slow growing species. A few studies investigated the fungal culture incubation time and generated mixed results. Morris et al. reviewed over 2,700 consecutive clinical cultures and determined that $98 \%$ of fungal isolates were detected by day 14 (5). Labarca et al. evaluated close to 4,000 positive fungal cultures and concluded that isolates recovered during the fourth week were rarely clinically significant (6). Bosshard's study suggested that two weeks incubation was sufficient for non-dermatophyates evaluation, whereas a 4-week incubation was necessary for recovery of dermatophytes (7). Hove and Woods 
reviewed their experience in an area endemic for Histoplasma capsulatum. Their study showed that 18 of 62 H. capsulatum isolates were recovered in week 3 and 4 (8).

To overcome the poor sensitivity of fungal culture, additional diagnostic tests were developed. Testing for antigen and fungal biomarkers are often used in addition to culture to help establish diagnosis (4). PCRbased assays targeting various genetic regions have been developed to improve the diagnostic yield, but mostly restricted to Apergillus and Candida species (9). In the situations when other opportunist pathogens can't be ruled out, molecular detection of a broad range of pathogens is desired. Broad-range internal transcribed spacer (ITS) rRNA gene PCR followed by sequencing holds promise for detection and identification of fungal pathogens in human samples (10). In a recent prospectively performed study, ITS PCR showed to be helpful for diagnosis of microscopy-negative fungal infections (11).

ITS PCR was implemented in 2013 in our lab. Our protocol requires infectious disease physicians specially request the test when a specimen from sterile source is fungal culture negative and the suspension for fungal infections is high. The purpose of this study was to review our experience with fungal culture in order to determine the optimal culture incubation time; to review our experience of ITS PCR for diagnosis of culture negative fungal infections.

\section{Materials And Methods}

Study design - We retrospectively reviewed the positive fungal cultures of clinical significant specimens recovered in the Clinical Microbiology Laboratory at Northwestern Memorial Hospital, a 900-teaching hospital in Chicago, were included between January 1, 2013 to December 31, 2017. Specimen types include abscess, body fluids, bronchoalveolar lavarge, endotracheal aspirate, sputum, skin, tissues, and wound. Information collected include fungal smear result, culture starting date, growth detection date, and species identification. Time to culture positivity was counted in days from culture started to the time when fungal growth was first detected.

Fungal stain and culture -Microscopic analysis of fungal smear was performed on all specimens with wet mount in $20 \% \mathrm{KOH}$ and with Calcofluor-white staining. Smear of sterile body fluids was prepared with cytospin centrifugation. Clinical specimens were cultured on Inhibitory mold agar plate and Brain and Heart Infusion agar plate. Plates were incubated at $30{ }^{\circ} \mathrm{C}$ in ambient air for four weeks. All plates were examined three times a week during the two weeks of incubation and then once a week afterwards. The time to detection of fungal growth was counted in days from culture started to the time when fungal growth was first detected.

ITS PCR - For culture negative patients with high clinical suspension for fungal infections, infectious disease physicians have access to order broad-range ITS PCR on the same specimen used for culture. When ITS PCR became positive, identification was determined with sequencing.

Nucleic acid extraction from clinical specimen was performed with the QIAamp DNA Mini Kit (QIAGEN, Hombrechtikon, Switzerlan) following the manufacturer's instruction. PCR amplification of the ITS region was performed with primers ITS1 5'- TCCGTA GGTGAACCTGCG G- 3' and ITS4 5'- TCCTCCGCTTATGATATG C - 3' 
as described preciously (12). PCR product was purified with QIAquick PCR purification kit (QIAGEN, Hombrechtikon, Switzerlan) and sequenced using BigDye kit (Life Technologies, Zug, Switzerland) and ABI 3130 Genetic analyzer kit (Life Technologies, Zug, Switzerland). Identification was obtained by BALST search against Genbank.

Medical record review -Electronic medical records were reviewed to determine the clinical significance of the organisms recovered by culture after 14 days of incubation and the organisms detected by ITS PCR. A result was determined to be clinically significant when the treating physician's diagnosis based on the test result was recorded in the patient chart and patient was treated for the identified organism.

\section{Results}

Time to growth detection - Forty two hundred and thirty four non-duplicated positive cultures were included in the study. Table 1 listed the fungal species recovered and their corresponding numbers. Cultured specimens included abscess, blood, eye (corneal scraping, vitreous fluid), skin, respiratory tract samples (sputum, endotracheal aspirate, BAL fluid), sterile body fluids (CSF, pericardial, peritoneal, and synovial fluids), and tissues. Twenty eight percent of samples (1219) had positive fungal smear. Nearly ninety six percent of positive cultures (4058) were detected in the first seven days of incubation. During the second week of incubation, $2.8 \%$ of positives (111) were detected from day 8 to 10 , and $1.7 \%$ (71) were detected from day 11 to 14 . Only $0.1 \%$ of positive culture were detected in the third week of incubation, and no positive culture was detected in the fourth week of incubation (Table 1). 
Table 1

Time to detection of fungal growth.

\begin{tabular}{|c|c|c|c|c|c|c|c|}
\hline Species & $\begin{array}{l}\text { Number } \\
\text { (\% of } \\
\text { total) }\end{array}$ & $\begin{array}{l}\text { Smear } \\
\text { positive } \\
(\%)\end{array}$ & $\begin{array}{l}\text { Days to } \\
\text { positive } \\
<=7\end{array}$ & $\begin{array}{l}\text { Days to } \\
\text { positive } \\
8-10\end{array}$ & $\begin{array}{l}\text { Days to } \\
\text { positive } \\
11-14\end{array}$ & $\begin{array}{l}\text { Days to } \\
\text { positive } \\
15-21\end{array}$ & $\begin{array}{l}\text { Days to } \\
\text { positive } \\
22-28\end{array}$ \\
\hline Candida spp. & $\begin{array}{l}3493 \\
(82.6)\end{array}$ & $\begin{array}{l}1009 \\
(28.9)\end{array}$ & $\begin{array}{l}3468 \\
(99.3)\end{array}$ & $23(0.6)$ & $2(0.1)$ & $0(0)$ & 0 \\
\hline Aspergillus spp. & $\begin{array}{l}244 \\
(5.8)\end{array}$ & $\begin{array}{l}94 \\
(38.5)\end{array}$ & $\begin{array}{l}231 \\
(94.7)\end{array}$ & $13(5.3)$ & $0(0)$ & $0(0)$ & 0 \\
\hline Penicillium spp. & $\begin{array}{l}117 \\
(2.8)\end{array}$ & $2(1.7)$ & $85(72.6)$ & $14(12)$ & 15 (12.8) & $3(2.6)$ & 0 \\
\hline $\begin{array}{l}\text { Dimorphic } \\
\text { fungia }^{a}\end{array}$ & $99(2.3)$ & $\begin{array}{l}37 \\
(37.4)\end{array}$ & $40(40.4)$ & $22(22.2)$ & $37(37.4)$ & $0(0)$ & 0 \\
\hline Other yeast ${ }^{\mathrm{b}}$ & $59(1.4)$ & $\begin{array}{l}20 \\
(33.9)\end{array}$ & $58(98.3)$ & $1(1.7)$ & $0(0)$ & $0(0)$ & 0 \\
\hline $\begin{array}{l}\text { Dematiaceous } \\
\text { fungic }\end{array}$ & $67(1.6)$ & $\begin{array}{l}10 \\
(14.9)\end{array}$ & $36(53.7)$ & $20(29.9)$ & $11(16.4)$ & $0(0)$ & 0 \\
\hline $\begin{array}{l}\text { Hyaline } \\
\text { Hyphomycetes }^{\mathrm{d}}\end{array}$ & $44(1.0)$ & $7(15.9)$ & $38(86.4)$ & $2(4.5)$ & $1(2.3)$ & $3(6.8)$ & 0 \\
\hline $\begin{array}{l}\text { Scedosporium } \\
\text { spp. }\end{array}$ & $36(0.9)$ & $\begin{array}{l}16 \\
(44.4)\end{array}$ & $28(77.8)$ & $7(19.4)$ & $1(2.8)$ & $0(0)$ & 0 \\
\hline Zygomyces $^{\mathrm{e}}$ & $34(0.8)$ & $\begin{array}{l}15 \\
(44.1)\end{array}$ & $34(100)$ & $0(0)$ & $0(0)$ & $0(0)$ & 0 \\
\hline Dermatophytes ${ }^{f}$ & $22(0.5)$ & $3(13.6)$ & $10(45.4)$ & $8(36.4)$ & $4(18.2)$ & $0(0)$ & 0 \\
\hline $\begin{array}{l}\text { Crytpococcus } \\
\text { neoformans }\end{array}$ & $16(0.3)$ & $6(37.5)$ & $15(93.8)$ & $1(6.2)$ & $0(0)$ & $0(0)$ & 0 \\
\hline Total & 4234 & $\begin{array}{l}1219 \\
(28.8)\end{array}$ & $\begin{array}{l}4058 \\
(95.8)\end{array}$ & $111(2.6)$ & $71(1.7)$ & $6(0.1)$ & 0 \\
\hline \multicolumn{8}{|c|}{ 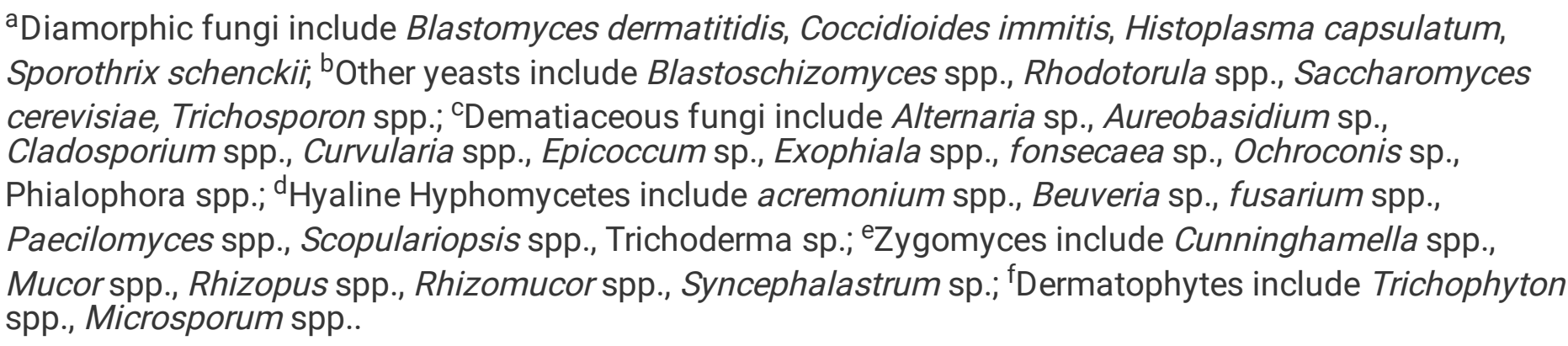 } \\
\hline
\end{tabular}

Time required for recovery of different species varied. Of 4058 (95.8\%) cultures growing yeast including Candida spp., Crytpococcus neoformans, and other yeast species, almost all of them, except two were recorded positive in less than 10 days of incubation. Growth of Candida spp. was detected in two cultures on 
day 11. Growth of Aspergillus spp. and Zygomyces was not detected after day 10. Fungal species belong to dimorphic fungi, dematiaceous fungi, and Dermatophates required longer incubation time with growth of $59.6 \%$ dimorphics, $46.3 \%$ dematiaceous fungi, and $52.2 \%$ Dermatophates was detected in the second week of incubation. The time to detection of different fungi groups was listed in Table 1.

Clinical significance of fungal isolates recovered after 14 days - The patients with a positive culture detected after 14 days were further investigated to determine the clinical significance of the recovered organisms. Three patients (patient $1,2,5$ ) had no sign of infection at the specimen collection site and did not receive treatment for the recovered organism. The symptoms of the other three patients (patient $3,4,7$ ) were attributed to either bacterial or viral infections based on the clinical course and treatment response. The recovered fungal organisms had not clinical significance. The last patient in the group (patient 6) was evaluated for presenting a lung mass. Bronchial wash was collected. Patient was later diagnosed with squamous cell lung carcinoma. Penicillium spp. recovered from the bronchial wash had no clinical significance. The summary of patient history and clinical information was listed in Table 2. 
Table 2

Patients with positive culture after 14 days of incubation

\begin{tabular}{|c|c|c|c|c|c|c|}
\hline Patient & Specimen & $\begin{array}{l}\text { Culture } \\
\text { Identification }\end{array}$ & $\begin{array}{l}\text { Time to } \\
\text { detection } \\
\text { of } \\
\text { growth } \\
\text { (days) }\end{array}$ & Patient History & $\begin{array}{l}\text { Reason for } \\
\text { Culture }\end{array}$ & $\begin{array}{l}\text { Clinical } \\
\text { Information }\end{array}$ \\
\hline 1 & $\begin{array}{l}\text { Skin } \\
\text { Biopsy }\end{array}$ & $\begin{array}{l}\text { Paecilomyces } \\
\text { spp. }\end{array}$ & 19 & $\begin{array}{l}\text { Renal } \\
\text { transplantation }\end{array}$ & $\begin{array}{l}\text { One month } \\
\text { of scattered } \\
\text { papular } \\
\text { lesions on } \\
\text { extremities }\end{array}$ & $\begin{array}{l}\text { No finding to } \\
\text { suggest for } \\
\text { infection by } \\
\text { surgical } \\
\text { pathological } \\
\text { examination. }\end{array}$ \\
\hline 2 & BAL & $\begin{array}{l}\text { Acremonium } \\
\text { spp. }\end{array}$ & 20 & $\begin{array}{l}\text { Lung } \\
\text { transplant }\end{array}$ & $\begin{array}{l}\text { Left } \\
\text { ureteral } \\
\text { stone }\end{array}$ & $\begin{array}{l}\text { No findings to } \\
\text { suggest for } \\
\text { infection by chest } \\
\text { X-ray. }\end{array}$ \\
\hline 3 & Sputum & $\begin{array}{l}\text { Acremonium } \\
\text { spp. }\end{array}$ & 22 & HIV on HAART & $\begin{array}{l}\text { Suspected } \\
\text { for hospital } \\
\text { acquired } \\
\text { pneumonia }\end{array}$ & $\begin{array}{l}\text { Patient } \\
\text { responded well to } \\
\text { vancomycin and } \\
\text { pipera } \\
\text { cillin/tazobactam } \\
\text { treatment. }\end{array}$ \\
\hline 4 & Sputum & $\begin{array}{l}\text { Acremonium } \\
\text { spp. }\end{array}$ & 25 & $\begin{array}{l}\text { Bioprosthetic } \\
\text { aortic valve }\end{array}$ & $\begin{array}{l}\text { Hemoptysis } \\
\text { with } \\
\text { abnormal } \\
\text { chest X ray }\end{array}$ & $\begin{array}{l}\text { Hemoptysis } \\
\text { resolved and } \\
\text { serial CXRs } \\
\text { showed } \\
\text { resolution of } \\
\text { persistent RLL } \\
\text { infiltrate after } \\
\text { empiric antibiotic } \\
\text { treatment. }\end{array}$ \\
\hline 5 & Wound & $\begin{array}{l}\text { Penicilium } \\
\text { spp. }\end{array}$ & 15 & $\begin{array}{l}\text { Colon } \\
\text { carcinoma and } \\
\text { asthma }\end{array}$ & $\begin{array}{l}\text { Evaluation } \\
\text { prior to } \\
\text { planned } \\
\text { ventral } \\
\text { hernia } \\
\text { repair } \\
\text { surgery }\end{array}$ & No infection \\
\hline 6 & $\begin{array}{l}\text { Bronchial } \\
\text { wash }\end{array}$ & $\begin{array}{l}\text { Penicilium } \\
\text { spp. }\end{array}$ & 15 & $\begin{array}{l}\text { No significant } \\
\text { past medical } \\
\text { history }\end{array}$ & Lung mass & $\begin{array}{l}\text { Sequamous cell } \\
\text { carcinoma }\end{array}$ \\
\hline 7 & BAL & $\begin{array}{l}\text { Penicilium } \\
\text { spp. }\end{array}$ & 19 & $\begin{array}{l}\text { No significant } \\
\text { past medical } \\
\text { history }\end{array}$ & $\begin{array}{l}\text { Cough, } \\
\text { fatigue \& } \\
\text { decreased } \\
\text { appetite }\end{array}$ & $\begin{array}{l}\text { Upper respiratory } \\
\text { viral infection }\end{array}$ \\
\hline
\end{tabular}


Table 3

Identification by ITS sequencing.

\begin{tabular}{|c|c|c|c|c|}
\hline Patient History & $\begin{array}{l}\text { Clinical Indication for } \\
\text { fungal culture }\end{array}$ & Specimen & $\begin{array}{l}\text { Direct } \\
\text { Microscopic } \\
\text { Examination }\end{array}$ & $\begin{array}{l}\text { Identification by } \\
\text { ITS Sequencing }\end{array}$ \\
\hline $\begin{array}{l}\text { Acute myeloid } \\
\text { leukemia (AML) }\end{array}$ & $\begin{array}{l}\text { Disseminated fungal } \\
\text { infection involving } \\
\text { multiple organs }\end{array}$ & $\begin{array}{l}\text { Apical mass, } \\
\text { liver biopsy, } \\
\text { pericardium }\end{array}$ & Positive & $\begin{array}{l}\text { Saccaromyces } \\
\text { cerevisiae }\end{array}$ \\
\hline $\begin{array}{l}\text { Recent history of } \\
\text { pneumonia requiring } \\
\text { hospitalization }\end{array}$ & $\begin{array}{l}\text { Left cerebellar lesion on } \\
\text { imaging }\end{array}$ & Brain tissue & Positive & $\begin{array}{l}\text { Blastomyces } \\
\text { dermatitidis }\end{array}$ \\
\hline Heart transplantation & Cavitary pneumonia & BAL & Negative & $\begin{array}{l}\text { Rhizopus } \\
\text { microsporus }\end{array}$ \\
\hline Renal transplantation & $\begin{array}{l}\text { Multiloculted cystic lesion } \\
\text { medial to transplanted } \\
\text { kidney in left pelvis }\end{array}$ & Blood & Negative & $\begin{array}{l}\text { Histoplasma } \\
\text { capsulatum }\end{array}$ \\
\hline $\begin{array}{l}\text { Hydrocephalus with } \\
\text { a ventriculoperitoneal } \\
\text { shunt }\end{array}$ & Brain lesion & Brain tissue & Positive & $\begin{array}{l}\text { Rhodotorula } \\
\text { spp. }\end{array}$ \\
\hline Renal transplantation & $\begin{array}{l}\text { Cavitary lung } \\
\text { lesions/pulmonary nodule }\end{array}$ & CSF & Negative & Aspergillus \\
\hline AML & $\begin{array}{l}\text { Pneumonia, sinusitis and } \\
\text { periorbital cellulitis }\end{array}$ & Ethmoid & Negative & Fusarium spp. \\
\hline Stage III Wilms tumor & Skin lesion & Scalp lesion & Positive & Rhizopus spp. \\
\hline AML & Cutaneous fungal lesions & Skin biopsy & Positive & Fusarium spp. \\
\hline Pregnancy & $\begin{array}{l}\text { Severe amniotic fluid } \\
\text { infection }\end{array}$ & $\begin{array}{l}\text { Placenta } \\
\text { tissue }\end{array}$ & Positive & $\begin{array}{l}\text { Candida } \\
\text { glabrata }\end{array}$ \\
\hline AML & $\begin{array}{l}\text { Neutropenic fevers and } \\
\text { pulmonary nodules }\end{array}$ & Tissue & Negative & Aspergillus spp. \\
\hline AML & $\begin{array}{l}\text { Disseminated fungal } \\
\text { infection with empyema, } \\
\text { pericarditis }\end{array}$ & $\begin{array}{l}\text { Pericardial } \\
\text { abscess }\end{array}$ & Positive & $\begin{array}{l}\text { Candida } \\
\text { tropicalis }\end{array}$ \\
\hline Renal transplantation & Pulmonary cavitary lesion & $\begin{array}{l}\text { TISC-left } \\
\text { upper lobe } \\
\text { region }\end{array}$ & Negative & $\begin{array}{l}\text { Cunningmahella } \\
\text { spp. }\end{array}$ \\
\hline $\begin{array}{l}\text { No significant } \\
\text { medical history }\end{array}$ & Liver abscess & Liver biopsy & Positive & $\begin{array}{l}\text { Candida } \\
\text { lusitaniae }\end{array}$ \\
\hline Renal transplantation & $\begin{array}{l}\text { Disseminated invasive } \\
\text { Aspergillosis involving } \\
\text { multiple organs }\end{array}$ & Brain tissue & Positive & Aspergillus spp. \\
\hline Renal transplantation & $\begin{array}{l}\text { Mass in the left sinus } \\
\text { invading the orbit }\end{array}$ & Eye tissue & Negative & Aspergillus spp. \\
\hline
\end{tabular}


Broad - range ITS PCR for diagnosis of fungal infections - 523 samples were tested with ITS PCR. Clinical significant pathogens were detected in culture negative samples from 16 patients, including five patients with acute myeloid leukemia, six transplantation patients, two patients with no significant past medical history, one cancer patient, one pregnant patient, and one patient with ventriculoperitoneal shun for hydrocephalus. Presence of morphologically consistent fungal organism was observed on fungal smear in nine (56\%) samples. The identifications were evaluated by the clinical team and the patients received treatment for the identified organisms.

\section{Discussion}

Our experience with fungal culture and ITS PCR from 2013 to 2017 was reviewed in this study. Forty two hundred and thirty four non-duplicated positive cultures from clinically significant sources were reviewed for time to positivity. Even though time required for recovery of different species varied, detection of growth was less than 14 days in $99.9 \%$ of cultures. Organisms recovered after 14 days had no clinical significance. ITS PCR yielded clinically significant positive results for culture negative samples from patients with high suspension for fungal infection.

Manual of Clinical Microbiology recommends that cultures that screen for Candida spp. need to be incubated for no longer than $72 \mathrm{~h}$, cultures that screen for dermatophates need to be incubated for only 8 days, and cultures screening for all pathogens should be held for 4 weeks. With increased immunocompromised population and aggressive use of immunosuppressive therapy, fungal culture has to cover wide range of organisms for most specimen types. As a result, incubation of fungal culture for 4 weeks is a common practice in most of clinical microbiology laboratories. The extended incubation time not only delays reporting of negative culture result, but also increases the chance of recovering contaminant. Only seven samples grew fungal species after 14 day incubation. In all seven patients, the organisms recovered by culture were determined to be clinically irrelevant by treating physicians. Among the seven isolates recovered after 14 days, three of them were Penicilium spp. Although Penicilium spp. was the third most commonly isolated fungal species in our study, the clinical significance of the most cultures with Penicilium spp. was questionable. Our study showed that average $30 \%$ of culture positive samples had positive fungal smear. Smear positive samples with Scedosporium spp. and Zygomyces accounted more than $44 \%$ of culture positive samples. However, only $1.2 \%$ of samples that grew Penicimium spp. were smear positive, which raise the question about clinical relevance of the species recovered during extended incubation.

A previous report examining the incubation time for recovering $H$. capsulatum in endemic area reported that up to 4-week incubation was required to recover the organism (8). Samples analyzed in the study included the samples from patients received anti-fungal treatments before samples collection. Delayed recovered of the dimorphic fungal species was not noted in our patients. In our study, dimorphic fungi species were recovered in 99 samples. The recovered isolates included 72 Blastomyces dermatitidis, 15 Coccidioides immitis, 9 H. capsulatum, and 2 sporotrichum schenckii. Of these samples, $40.4 \%$ samples were found to be culture positive after 1 week, $22.2 \%$ were positive after 2 weeks, and $37.4 \%$ were positive after 3 weeks. All the samples were collected before treatment initiation. Our results indicated that fungal treatment can significantly delay the development of positive fungal culture. 
We showed that clinical significant pathogens were detected in culture negative samples by ITS PCR in samples from 16 patients. Low sensitivity of culture has been reported for several important fungal pathogens. Reported rate of pathogen recovery from culture ranged from $8-31 \%$ (13). Culture-independent laboratory tests based on detection of antibodies, antigens, or metabolites have been developed, their application for diagnosis of invasive fungal infections suffers from lack of specificity, sensitivity, or being unable to provide species level information. ITS PCR followed by sequencing has become the cultureindependent method of choice for the advantage of allowing for rapid detection and identification of fungi in clinical specimens. A recent study to evaluate the Performance of Targeted Fungal Sequencing for CultureIndependent Diagnosis of Invasive Fungal Disease reported the method had $62.9 \%$ of diagnostic yield in patients with suspected invasive fungal infections. In our study, the ITS PCR positive rate was much lower, only $0.2 \%$. Two main factors may contribute the low positive rate. First, we included all samples that had been tested with ITS PCR regardless of the clinical suspicion for fungal infections. Because of the reported high sensitivity of ITS PCR for detection of fungi in clinical samples, the test was often used by clinicians as a rule-out test. The number of patients underwent testing who had true clinical suspicion for fungal infections was unknown. Second, we did not have minimal requirement for sample size. As ITS PCR was used as the last resort in clinical practice, the sample remains for PCR was scant.

\section{Conclusion}

Different from the studies that examined the fungal culture time and published before 2013, our study reviewed the data collected in the recent years, reflecting the laboratory practice in response to the increased incidence of invasive fungal disease as a result of the expansion of immunocompromised populations. In addition, the utility of ITS PCR as a last resort to assist the diagnosis of fungal infections was reviewed. Our study concluded that extending culture incubation beyond two weeks did not generate clinical relevant results. When culture failed to make laboratory diagnosis, ITS PCR produced clinical significant results.

\section{Declarations}

\section{Authors' Contributions}

AZ: conceptualization, methodology, investigation, formal analysis, data curation, and the original draft preparation

CQ: resources, manuscript review and editing

\section{Conflicts of interest}

The authors declare that they have no competing interests.

\section{Funding information}

None

\section{Ethical approval}


The human study protocol was approved by the institution review board of Northwestern University.

\section{Consent for publication}

Consent was obtained from participants for publication.

\section{References}

1. Enoch DA, Yang H, Aliyu SH, Micallef C. The Changing Epidemiology of Invasive Fungal Infections. Methods in molecular biology (Clifton, NJ). 2017;1508:17.

2. Horn DL, Neofytos D, Anaissie EJ, Fishman JA, Steinbach WJ, Olyaei AJ, et al. Epidemiology and outcomes of candidemia in 2019 patients: data from the prospective antifungal therapy alliance registry. (Clinical report). Clinical Infectious Diseases. 2009;48(12):1695.

3. Neofytos D, Fishman JA, Horn D, Anaissie E, Chang CH, Olyaei A, et al. Epidemiology and outcome of invasive fungal infections in solid organ transplant recipients. Transplant Infectious Disease. 2010;12(3):220.

4. Lamoth F, Calandra T. Early diagnosis of invasive mould infections and disease. Journal Of Antimicrobial Chemotherapy. 2017;72(suppl_1):i19.

5. Morris AJ, Byrne TC, Madden JF, Reller LB. Duration of incubation of fungal cultures. Journal Of Clinical Microbiology. 1996;34(6):1583.

6. Labarca JA, Wagar EA, Grasmick AE, Kokkinos HM, Bruckner DA. Critical Evaluation of 4-Week Incubation for Fungal Cultures: Is the Fourth Week Useful? Journal Of Clinical Microbiology. 1998;36(12):3683.

7. Bosshard PP. Incubation of fungal cultures: how long is long enough? Mycoses. 2011;54(5):e539.

8. Hove MGM, Woods GL. Duration of fungal culture incubation in an area endemic for Histoplasma capsulatum. Diagnostic Microbiology \&amp; Infectious Disease. 1997;28(1):41.

9. Dunyach C, Bertout S, Phelipeau C, Drakulovski P, Reynes J, Mallié M. Detection and identification of Candida spp. in human serum by LightCycler ${ }^{\circledR}$ real-time polymerase chain reaction. Diagnostic Microbiology \&amp; Infectious Disease. 2008;60(3):263.

10. Babouee B, Goldenberger D, Elzi L, Lardinois D, Sadowski-Cron C, Bubendorf L, et al. Prospective study of a panfungal PCR assay followed by sequencing, for the detection of fungal DNA in normally sterile specimens in a clinical setting: a complementary tool in the diagnosis of invasive fungal disease? Clinical Microbiology and Infection. 2013;19(8):e354.

11. Lass-Flörl C, Mutschlechner W, Aigner M, Grif K, Marth C, Girschikofsky M, et al. Utility of PCR in Diagnosis of Invasive Fungal Infections: Real-Life Data from a Multicenter Study. Journal Of Clinical Microbiology. 2013;51(3):863.

12. White TJ, Bruns, T., Lee., S., Taylor, J. Amplification and sequencing of fungal ribosomal RNA genes for phylogenetics. PCR protocols: a guide to methods and applications. 1990;18:7.

13. Sidiq F, Hoostal M, Rogers SO. Rapid identification of fungi in culture-negative clinical blood and respiratory samples by DNA sequence analyses.(Clinical report). BMC Research Notes. 2016;9(1). 
14. Klont RR, Meis JF, Verweij PE. Critical assessment of issues in the diagnosis of invasivea spergillosis. Clinical microbiology and infection : the official publication of the European Society of Clinical Microbiology and Infectious Diseases. 2001;7 Suppl 2:32. 